\title{
An analysis on the delay of cervical cancer patients in seeking medical check up in Dr. Cipto Mangunkusumo National Central General Hospital Jakarta
}

\author{
Ni Nengah Susanti ${ }^{*}$ M. Farid Aziz ${ }^{\#}$, Adang Bachtiar ${ }^{f}$
}

\begin{abstract}
Abstrak
Di Indonesia umumnya pasien kanker serviks datang berobat pada stadium lanjut (62\%) sehingga kanker serviks merupakan $66 \%$ dari penyebab kematian ginekologik. ${ }^{1}$ Tujuan penelitian ini adalah untuk mengetahui faktor-faktor yang berhubungan dengan keterlambatan pasien kanker serviks memeriksakan diri. Penelitian menggunakan metode kuantitatif dan kualitatif dengan sampel yang diambil dari seluruh pasien baru kanker serviks tahun 2000 dan 2001 yang datang berkunjung kembali ke RSUPN Dr. Cipto Mangunkusumo Jakarta pada bulan Agustus sampai dengan Oktober 2001. Kesimpulan : Variabel yang berhubungan secara signifikan dengan waktu memeriksakan diri ialah pengetahuan, sikap, ketersediaan pelayanan Pap smear dan dukungan suami. Ketersediaan pelayanan Pap smear merupakan variabel yang dominan. (Med J Indones 2003; 12: 162-5)
\end{abstract}

\begin{abstract}
In Indonesia, most cervical cancer patients seek medical help after the cancer has reached advanced stage (62\%). This has caused cervical cancer to contribute to $66 \%$ of gynecological deaths. ${ }^{I}$ The objective of this study is to find out factors related to the delay of cervical cancer patients in seeking for medical help. This research employs quantitative and qualitative methods. Samples were obtained from all of the new cervical cancer patients who came for the first time between 2000 to 2001 and returned to the Dr. Cipto Mangunkusumo National Central General Hospital Jakarta from August until October 2001. It is concluded that variables significantly correlated with the delay for medical check up are knowledge, attitude, the availability of Pap smear service and husband support. The availability of Pap smear plays as dominant variabel. (Med J Indones 2003; 12: 162-5)
\end{abstract}

Keywords: Cervical cancer, knowledge, attitude, the availability of Pap smear service, husband support, late medical check up.

At the Dr. Cipto Mangunkusumo National Central General Hospital Jakarta, cervical cancer patients who visited the hospital after the cancer reached advanced stage (IIb - IV) were up to $62 \%$. This condition has contributed to $66 \%$ of gynecological deaths. Mother's death has great impact on the family life and the society as well; especially as it affects the continuity of the young generation. Therefore, it is necessary to study the factors connected to the delay of cervical cancer patients in seeking for medical help.

\footnotetext{
* Nursing Academy of Health, Department of Health, Jakarta, Indonesia

\# Department of Obstetrics and Gynecology, Faculty of Medicine, University of Indonesia, Jakarta, Indonesia

${ }^{f}$ Faculty of Public Health, University of Indonesia, Jakarta, Indonesia
}

Based on Green theory, the attitude and manner in help seeking is influenced by 3 groups of factors, which are predisposing, enabling and reinforcing. ${ }^{2}$ Predisposing factors relate to among others belief, value, knowledge and perception which either supports or hinders one's motivation to change. Enabling factors consisted of financial ability, transportation and health service availability. While the reinforcing factor is support from others.

\section{METHODS}

Samples were obtained purposively from new patients diagnosed as cervical cancer that visited RSUPN-CM from August 2000 until October 2001, which were 124 patients, consisted of 38 patients with early stage and 86 patients with advanced stage. The first group of 
early stages (I - IIa), constituted those who underwent medical check up on time. The second group was advanced stages (IIb - IV), which was categorized as those who were late in conducting medical check up.

The research was carried out with cross sectional quantitative approach. The result of data collection were analyzed and cultivated with computer. Meanwhile, digging deeper of patient's understanding about cervical cancer and early detection was employed using a qualitative method. Samples for the qualitative research consisted of 6 patients who were chosen based on sufficiency in their appropriateness and representativeness. They consisted of 2 early stage patients, 2 stage III patients, 1 midwife (midwife from neoplasm polyclinic) and husband of 1 patient. Source triangulation method was carried out to attain valid data, through cross checking with 1 midwife and patient's husband. The triangulation method was maintained through deeper probing interview, observation and analysis of documents. After the data was collected, it was then analyzed using content analysis. ${ }^{1}$

\section{RESULTS}

The number of new patients diagnosed as suffering cervical cancer that visited the hospital in August 2000 - October 2001 were 24 patients. They consisted of 38 (30.6\%) patients belonging to the early stage and 86 (69.4\%) advanced staged patients. The result of respondents' characteristics showed that most of them ( 54.8 $\%$ ) were of aged $40-59$ and almost all of them (90.3\%) were married at an early age of $<20$ years old (table 1 ).

The result of univariate analysis in table 2 indicated that most respondents showed lack of knowledge (58.9 \%), negative attitude $(56.5 \%)$, unability to pay financial costs for medical attention (65.3\%), and lack of husband's support $(64.5 \%)$. This data was supported by the interview which showed that the patients learned about cervical cancer and Pap smear only after they suffered the illness.

Table 1. Respondent's Characteristics Based on Age, Marriage, Abortion, Giving Birth, and Medical Check up.

\begin{tabular}{lc}
\hline \multicolumn{1}{c}{ Respondent's Characteristics } & $\%$ \\
\hline Age 40 -59 & 54.8 \\
Married age I ${ }^{\text {st }}<20$ & 90.3 \\
Married > 1x & 4.8 \\
Giving birth > 3x & 62.9 \\
Abortion > 1x & 10.5 \\
Delay in medical check up & 69.4 \\
Normal medical check up & 30.6 \\
\hline
\end{tabular}

The result of univariate analysis in table 2 indicated that most respondents showed lack of knowledge (58.9 \%), negative attitude $(56.5 \%)$, unability to pay financial costs for medical attention (65.3\%), and lack of husband's support $(64.5 \%)$. This data was supported by the interview which showed that the patients learned about cervical cancer and Pap smear only after they suffered the illness.

Table 2. Analysis Result of Univariate Analysis

\begin{tabular}{lc}
\hline \multicolumn{1}{c}{ Respondent's Characteristic, $\mathrm{n}=124$} & $\%$ \\
\hline Lack of Knowledge & 58.9 \\
Negative Attitude & 56.5 \\
Unavailability of Pap smear & 49.2 \\
Unable to finance the medical cost & 65.3 \\
The absence of support from medical officer & 42.7 \\
Lack of husband support & 64.5 \\
\hline
\end{tabular}

Table 3 confirmed that the significant variables affecting the delay of cervical cancer patients to seek medical check up were lack of knowledge on the disease, negative attitude, unavailability of Pap smear service and lack of husband support $(\mathrm{p}<0.05)$. This was supported by the interview result stating that lack of knowledge and information on cervical cancer resulted in their lateness in undergoing medical check up.

Table 3. Result of Bivariate Analysis

\begin{tabular}{lccccc}
\hline \multicolumn{1}{c}{ Variable } & \multirow{2}{*}{ Proportion (\%) } & p & OR & 95\% CI \\
\hline Proportion of lack of knowledge from adequate & 67.4 & 32.6 & 0.007 & 3.18 & $1.439: 7.009$ \\
Proportion of negative attitude from positive & 64.0 & 36.0 & 0.019 & 2.72 & $1.240: 5.967$ \\
Proportion of the unavailability of Pap test service from none & 60.5 & 39.5 & 0.0001 & 4.93 & $2.077: 11.690$ \\
Proportion of lack of financial ability from adequate & 67.4 & 32.6 & 0.588 & 1.351 & $0.612: 2.981$ \\
Proportion of the absence of support from medical officer & 45.3 & 54.7 & 0.493 & 1.422 & $0.649: 3.116$ \\
from presence & & & & & \\
Proportion of lack of husband support from adequate & 70.9 & 29.1 & 0.019 & 2.44 & $1.110: 5.366$ \\
\hline
\end{tabular}


The result of multivariate analysis indicated that lack of Pap smear service centers stood as a dominant variable in causing the lateness for medical assistance. It's value was $\operatorname{Exp}=1.500$ which stayed on the highest rank. The result of correlation test showed value $\mathrm{p}=0.0001(\mathrm{p}<0.05)$. This showed that there is a strong correlation between the lack of knowledge and unavailability of Pap smear service centers with the delay of medical help seeking. This data supported by interview results, indicated that in almost all of the patients the distance of their living premises were too far from Pap smear service centers.

\section{DISCUSSION}

Cervical cancer has been ranked first among all gynecologic cancers, $62 \%$ of patients suffering from cervical cancer came for medical treatment after they reached advanced stage, which affects the morbidity and mortality rate. ${ }^{1}$ Our research result showed that variables significantly causing the delay in conducting medical check up were lack of knowledge, negative attitude, unavailability of Pap smear service, and lack of husband support $(\mathrm{p}<0.05)$. This data was supported by interview result, which indicated that their lack of knowledge about cervical cancer and Pap smear, was due to the absence of information agents, their fear of the disease and unavailability of Pap smear service, which altogether caused the delay in undergoing medical check up.

According to WHO report, one reason a person did not act properly was partly due to their way of thinking and feeling, which were influenced by their knowledge, perception, attitude, belief and judgment towards health objects. ${ }^{3}$ Judgment toward health object constituted self-examining attitude, and physical environment i.e. health care facility. Financial ability and support from medical officer did not significantly correlate with the delay in seeking medical help ( $p>0.05)$, which was supported by interview result. Further the interview showed that even though Pap smear service was relatively expensive, they would not refrain from attaining it, however, earlier research result showed that the reason in reporting late in their illness of $8 \%$ of the patients was due to the high cost of the medical service. ${ }^{4}$
Even though correlation of the support from medical officers' to the delay in conducting medical check up was not statistically significant, there were statements especially among the advanced staged patients, that lack of medical officers support were partly responsible for their lateness in approaching medical help. This condition was in line with the patients' denial attitude. ${ }^{5}$ In addition, reference from 'important' person in this case medical officers, also influence the patients behavior in seeking medical help. ${ }^{3}$ Patients' knowledge were measured through what they knew about cervical cancer \& Pap test, that set them off to seek for medical service as soon as they experience the symptoms. ${ }^{6}$ Other opinion stated that one's attitude towards health issues depended on pain stimulation and illness. ${ }^{7}$ Another scientist's combined theory stated that one's attitude towards health care service was based on the benefit and availability of health treatment and the quality of service. ${ }^{8}$ Other supporting factors involved were risk, seriousness, benefit and external symptoms. ${ }^{9}$

It is concluded that the study indicates that variables significantly correlated with the delay for medical check up are knowledge, attitude, the availability of Pap smear service and husband support. The availability of Pap smear service was the dominant variable.

We came up with a suggestion that all related parties should participate actively in promoting public counseling programs and early detection of cervical cancer, through an organized and systematic way; through Communication, Information and Education (KIE) which is coordinated in a cross sector way by the Indonesian Society of Obstetrics and Gynecology (POGI), the Indonesian Association of Midwives (IBI), the Indonesia Cancer Foundation (YKI) and the National Family Planning Coordination Board (BKKBN).

Furthermore, it is suggested to interested parties to develop this research by adding the number of subjects and combining with those from all though the nation, thus the result can be more generalized.

\section{Acknowledgements}

We would like to thank the head of the Department of Obstetrics and Gynecology, Faculty of Medicine University of Indonesia, Director of the Dr. Cipto Mangunkusumo National Central General Hospital, 
and would like to extend our heartfelt gratitude for the help of staff and member of the Oncology ward and clinic of the hospital, for making this study possible.

\section{REFERENCES}

1. Aziz MF. Screening and early detection of cervical cancer, In: Ramli M,ed. Early detection of cancer. Association Publisher of Faculty of Medicine University of Indonesia, Jakarta. 2000; p 97-110

2. Green WL, Kreuter WM, Deeds GS, Patridge BK. Health education planning. $1^{\text {st }}$ ed, California: Mayfield Publishing Co. $1980 ; 5$ : 116-147

3. World Health Organization. Health promotion in developing countries, Division of Health Education and Promotion, Geneva. 1989; p 9-13
4. Suchman E. Social pattern of illness and medical care, Journal of Health Human Behaviour. 1965; 6: 2-16

5. Engle. Nursing diagnosis, aplication in clinical practice. $6^{\text {th }}$ ed. Philadelphia, USA.1964; p 11-2

6. Bloom HE, in Notoatmodjo $\mathrm{S}$ et al, eds in Education, promotion, and health behaviour. Faculty of Public Health, University of Indonesia. Jakarta. 2000; 1 : 5-9

7. Skinner BF, Becker, in Notoatmodjo $\mathrm{S}$ et al, eds in Education promotion and health behaviour. Faculty of Public Health, University of Indonesia, Jakarta, 2000; 3 : $1-9$

8. Cumming, Elaine, Dean, Lois, Newell and David. Disengagement a tentative theory of aging, sociometry. 1960; $23: 23-37$.

9. Wolinsky FD. The Sociology of health, principles, porofessions and issues. Little Brown and Company, Boston, Toronto. 1980; p. 137-57 